\title{
LIMNOLOGICAL STUDY OF A PANTANAL SALINE LAKE
}

\author{
MEDINA-JÚNIOR, P. B. ${ }^{1}$ and RIETZLER, A. C. ${ }^{2}$ \\ ${ }^{1}$ Laboratório de Biodiversidade, Ecologia e Conservação de Ecossistemas Aquáticos, UNIDERP, \\ Av. Alexandre Herculano, 1400, CEP 79002-800, Campo Grande, MS, Brazil \\ ${ }^{2}$ Depto de Biologia Geral, ICB-UFMG, Av. Antônio Carlos, 6627, \\ CEP 31270-901, C. P. 486, Belo Horizonte, MG, Brazil \\ Correspondence to: Paulino Barroso Medina Júnior, Laboratório de Biodiversidade, \\ Ecologia e Conservação de Ecossistemas Aquáticos, UNIDERP, Av. Alexandre Herculano, 1400, \\ CEP 79002-800, Campo Grande, MS, Brazil, e-mail: medinajr@bol.com.br \\ Received October 14, 2003 - Accepted December 17, 2003 - Distributed November 30, 2005
}

(With 4 figures)

\begin{abstract}
Limnological studies involving physical, chemical and biological aspects, with emphasis on the zooplankton community, were carried out in a saline lake of the Pantanal floodplain, in the subregion of Nhecolândia (Mato Grosso do Sul, Brazil), during the dry and wet seasons of the local hydrological cycle. The results show that the lake is not directly affected by the flood-pulse through superficial coalescence, probably receiving groundwater instead. Most of the measured variables showed extremely high values, particularly dissolved salts, $\mathrm{pH}$, conductivity, nutrients and chlorophyll $a$. These values were highest during the dry period due to the system's low water volume. The zooplankton community was basically represented by Metacyclops mendocinus, which displayed high population densities throughout the periods studied. The low diversity recorded is congruent with other studies on continental saline water-bodies.
\end{abstract}

Keywords: flood plain, pond, biodiversity, zooplankton.

\section{RESUMO}

\section{Estudo limnológico de uma lagoa salina do Pantanal}

Estudos limnológicos envolvendo aspectos físicos, químicos e biológicos, com ênfase na comunidade zooplanctônica, foram realizados em uma lagoa salina do Pantanal, sub-região de Nhecolândia (Mato Grosso do Sul, Brasil) considerando-se os períodos de seca e cheia dentro de um ciclo hidrológico local. Os resultados mostraram que a lagoa não sofreu a influência direta do pulso de inundação através da coalescência superficial, tendo sido alimentada, provavelmente, pelo lençol freático. Valores extremamente elevados foram encontrados para a maioria das variáveis medidas, destacando-se a concentração de sais dissolvidos, $\mathrm{pH}$, condutividade elétrica, nutrientes e clorofila $a$. Estes valores foram maiores no período de seca, em função da redução do volume de água no sistema. Em decorrência das condições limnológicas, a comunidade zooplanctônica foi basicamente representada por Metacyclops mendocinus, que apresentou elevadas densidades nos dois períodos estudados. A baixa diversidade encontrada corrobora com estudos feitos em outros ambientes continentais de água salgada.

Palavras-chave: planície de inundação, lagoa rasa, biodiversidade, zooplâncton.

\section{INTRODUCTION}

The Pantanal is a large floodplain whose dynamics are regulated primarily by the flood-pulse, whereby the seasonality of the hydrological regime, characterized by periods of flooding and drought, constitutes the primary factor governing the ecology of these plains. Considerable seasonal changes occur in the physical and chemical characteristics of the entire system, giving rise to a great diversity of habitats that favor a high diversity of terrestrial and aquatic plants and animals (Junk et al., 1989).

The Pantanal can be divided into subregions, each with specific characteristics and reacting 
differently to the pulses of inundation. Differences in amplitude and intensity of the floods between the subregions determine the formation of different types of aquatic ecosystems, thus amplifying the conditions for the establishment of diverse biological communities in these systems (Heckman, 1996).

The region of Nhecolândia, which occupies $19.48 \%$ of the Central Pantanal (Silva \& Abdon, 1998), differs from the Pantanal's other regions by presenting hundreds of small, shallow lakes that display varying degrees of salinity and coalescence with the system in flood.

Among these water bodies are what are locally known as "salinas", which occur in very low numbers and are restricted to the region. These salinas are protected from the flood-pulse by "cordilheiras" (the local name for continuous stretches of elevated land, of variable extension, generally covered by vegetation, which can act as natural barriers to flooding). The surfaces and shores of these saline lakes are devoid of vegetation, and their waters are blueish green due to high concentrations of cyanobacteria. These lakes enter into contact with flooded areas only in major flood situations.

Considering the peculiarities and the lack of limnological information on these ecosystems, the proposal of this study was to analyze the structure and diversity of the zooplankton community of a representative saline lake of the Central Pantanal region, taking into consideration possible effects of the hydrological regime on the system's limnological variables.

\section{STUDY AREA}

The system studied here is a saline lake ("Salina do Meio") on Nhumirim Ranch, situated in the center of the Pantanal of Nhecolândia, at $18^{\circ} 59^{\prime} \mathrm{S} 56^{\circ} 39^{\prime} \mathrm{W}$ (Fig. 1). In this subregion, the water that feeds the lakes is influenced principally

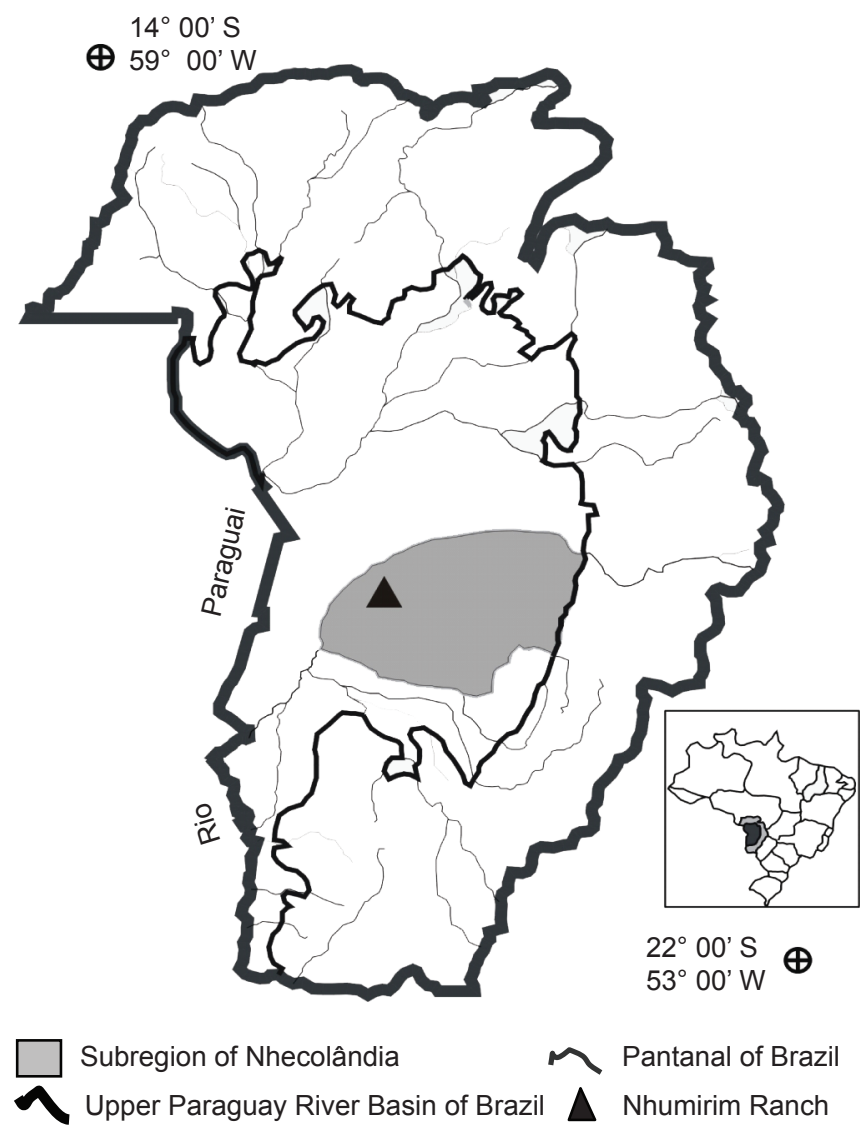

Fig. 1 - Position of the system studied in the Central Pantanal (modified from Silva \& Abdon, 1998). 
by rainfall, and to a lesser extent by the water table (Sakamoto et al., 1996).

This lake possesses the typical characteristics of the saline lakes of this subregion, having a circular shape, little depth and a diameter of approximately $80 \mathrm{~m}$. Similar to most of the region's lakes, this lake is protected from anthropogenic activity, serving as an important source of water for wildlife that prefer these lakes over freshwater lakes, probably because it provides minerals that complement their normal diet.

\section{MATERIALS AND METHODS}

Sampling was carried out within a complete local hydrological cycle, at the end of the dry season (September 1997) and the end of the wet season (June 1998). Rainfall data was obtained from Soriano (2000). Water transparency was measured with a Secchi Disc (30 cm in diameter), and temperature, $\mathrm{pH}$, dissolved oxygen, conductivity and salinity, were measured in situ with a Horiba U-10 water quality checker, at the top and bottom of the water column. Sub-superficial water samples were collected for analysis of chemical and biological variables in the laboratory (Table 1). The zooplankton community was sampled using a plankton net with a mesh size of $30 \mu \mathrm{m}$, with horizontal net hauls being made at different points for qualitative analysis. Quantitative samples were taken using a graduated bucket, filtering known volumes of water through the net. Samples were fixed in $4 \%$ formaldehyde.

The keys used to identify the zooplankton included the following: Pennak (1953), Edmondson (1959), Rocha \& Matsumura-Tundisi (1976), Reid (1985), Matsumura-Tundisi (1986), Reddy (1994), Dussart \& Defaye (1995).
Organism abundances were quantified using dissecting and conventional microscopes (Edmondson \& Winberg, 1971).

\section{RESULTS}

Rainfall data between September 1997 and August 1998 indicate the highest occurred in February $(280 \mathrm{~mm})$ while no rainfall occurred in July. The samples taken in September 1997 and June 1998 characterize the end of the dry season in 1997, and the end of the wet season in 1998 (Fig. 2).

The limnological variables analyzed are shown in Table 2. Water level varied greatly, with a maximum value of $0.40 \mathrm{~m}$ in the dry season, and $0.80 \mathrm{~m}$ in the wet. The euphotic zone was very shallow in both periods, i.e., $0.13 \mathrm{~m}$ in the dry and $0.21 \mathrm{~m}$ in the wet season.

Mean temperatures were quite high, i.e., $29.9{ }^{\circ} \mathrm{C}$ in the dry and $24.6{ }^{\circ} \mathrm{C}$ in the flood. High values of dissolved oxygen (17.2 and $\left.14.0 \mathrm{mg} . \mathrm{L}^{-1}\right)$ and $\mathrm{pH}(9.4$ and 9.0) were found in the dry and wet periods, respectively. Conductivity and salinity were also very high for continental waterbodies in natural conditions, especially in the dry period, with respective values of $8470.00 \mu \mathrm{s} . \mathrm{cm}^{-1}$ and $4.6 \mathrm{~g} . \mathrm{L}^{-1}$, more than twice the values obtained in the wet period.

Concentrations of suspended solids, nutrients, and chlorophyll a and phaeophytin were directly related to the hydrological regime, with values almost always higher during the dry period. The suspended material was mostly organic, corresponding to more than $90 \%$ in both periods.

As for nutrients, greater concentrations of the forms of nitrogen (with the exception of nitrate) were found in the dry period, with

TABLE 1

Chemical and biological variables measured, and references used.

\begin{tabular}{|l|l|}
\hline \multicolumn{1}{|c|}{ Variable analyzed } & \multicolumn{1}{c|}{ Reference } \\
\hline Suspended material $\left(\mathrm{mg} . \mathrm{L}^{-1}\right)$ & Teixeira et al., $1965 ;$ Tundisi, 1969 \\
\hline Chlorophyll $a$ and phaeophytin $\left(\mu \mathrm{g} . \mathrm{L}^{-1}\right)$ & Golterman et al., 1978 \\
\hline Total Kjeldahl nitrogen $\left(\mathrm{mg} . \mathrm{L}^{-1}\right)$ e nitrite & Golterman, et al., 1978 \\
\hline Nitrate $\left(\mu \mathrm{g} . \mathrm{L}^{-1}\right)$ & Mackereth et al., 1978 \\
\hline Ammonia $\left(\mu \mathrm{g} . \mathrm{L}^{-1}\right)$ & Koroleff, 1976 \\
\hline Total phosphorus $\left(\mu \mathrm{g} . \mathrm{L}^{-1}\right)$ & Standard Methods, 1995 \\
\hline Total dissolved inorganic phosphorus $\left(\mu \mathrm{g} . \mathrm{L}^{-1}\right)$ & Strickland \& Parsons, 1960 \\
\hline
\end{tabular}




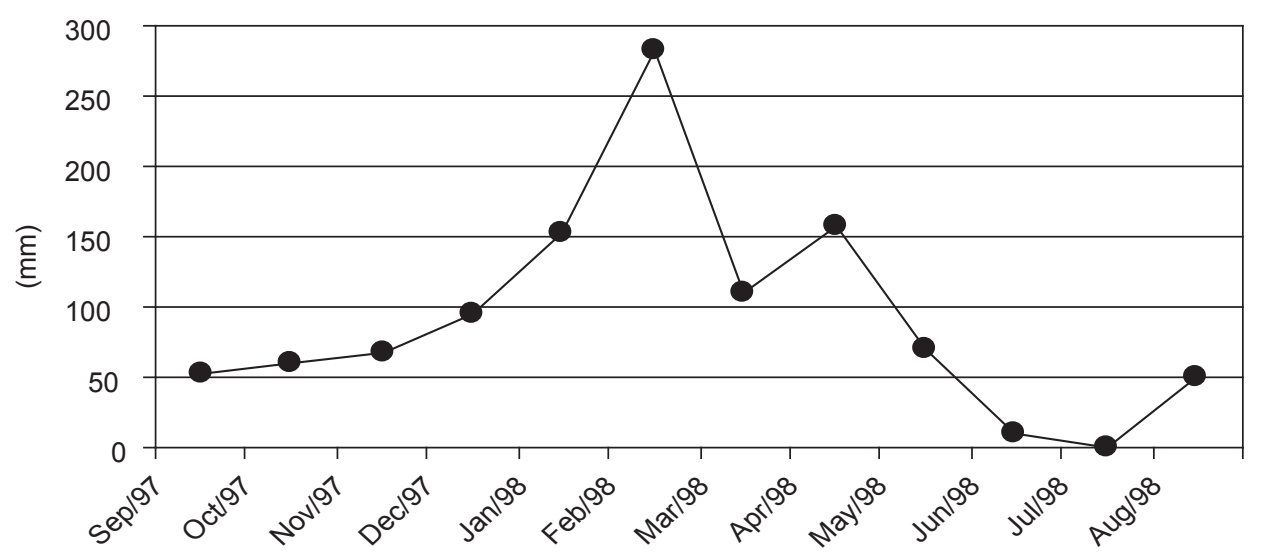

Fig. 2 - Total monthly rainfall during the 1997/1998 cycle at Nhumirim Ranch (according to Soriano, 2000).

TABLE 2

Physical, chemical and biological variables analyzed for the lake. Mean surface and bottom temperature, pH, oxygen, conductivity and salinity.

\begin{tabular}{|c|c|c|}
\hline \multirow[b]{2}{*}{ Limnological Variable } & \multicolumn{2}{|c|}{ Period } \\
\hline & Dry (September-97) & Wet (June-98) \\
\hline Maximum depth (m) & 0.40 & 0.80 \\
\hline Euphotic zone (m) & 0.13 & 0.21 \\
\hline Temperature $\left({ }^{\circ} \mathrm{C}\right)$ & 29.90 & 24.60 \\
\hline $\mathrm{pH}$ & 9.49 & 9.00 \\
\hline Dissolved oxygen (mg. $\left.\mathrm{L}^{-1}\right)$ & 17.20 & 13.90 \\
\hline Conductivity $\left(\mu \mathrm{s} . \mathrm{cm}^{-1}\right)$ & 8470.00 & 3950.00 \\
\hline Salinity $\left(\mathrm{g} . \mathrm{L}^{-1}\right)$ & 4.60 & 2.00 \\
\hline Total suspended material (mg.L ${ }^{-1}$ ) & 1379.50 & 243.80 \\
\hline Organic suspended material $\left(\mathrm{mg} . \mathrm{L}^{-1}\right)$ & 1242.50 & 229.20 \\
\hline Inorganic suspended material (mg.L $\left.\mathrm{L}^{-1}\right)$ & 137.00 & 14.50 \\
\hline Total nitrogen $\left(\mathrm{mg} . \mathrm{L}^{-1}\right)$ & 110.10 & 47.30 \\
\hline Nitrite $\left(\mu \mathrm{g} . \mathrm{L}^{-1}\right)$ & 27.80 & 8.90 \\
\hline Nitrate $\left(\mu \mathrm{g} . \mathrm{L}^{-1}\right)$ & 0.80 & 9.70 \\
\hline Ammonia $\left(\mu \mathrm{g} . \mathrm{L}^{-1}\right)$ & 77.80 & 44.00 \\
\hline Total phosphorus $\left(\mu \mathrm{g} . \mathrm{L}^{-1} \mathrm{l}\right)$ & 1534.40 & 1583.70 \\
\hline Total dissolved phosphate $\left(\mu \mathrm{g} . \mathrm{L}^{-1} \mathrm{l}\right)$ & 473.00 & 315.00 \\
\hline Dissolved inorganic phosphate $\left(\mu \mathrm{g} . \mathrm{L}^{-1} \mathrm{l}\right)$ & $*$ & 43.00 \\
\hline Chlorophyll $a\left(\mu \mathrm{g} . \mathrm{L}^{-1}\right)$ & 2064.60 & 1025.30 \\
\hline Phaepohytin $\left(\mu \mathrm{g} . \mathrm{L}^{-1}\right)$ & 347.40 & 332.00 \\
\hline
\end{tabular}

*Not analyzed

$110.0 \mathrm{mg} . \mathrm{L}^{-1}$ of total nitrogen being recorded. The concentrations of the forms of phosphorus did not vary greatly between the periods studied. Mean values of total phosphorus were $1534.40 \mu \mathrm{g} . \mathrm{L}^{-1}$ and $1583.70 \mu \mathrm{g} . \mathrm{L}^{-1}$ in the dry and wet periods, respectively.
Chlorophyll $a$ values were extremely high in both periods, albeit higher in the dry period than in the wet $\left(2064.60 \mu \mathrm{g} . \mathrm{L}^{-1}\right.$ vs. $\left.1025.30 \mu \mathrm{g} . \mathrm{L}^{-1}\right)$.

With regard to the zooplankton, one species of copepod was recorded, Metacyclops mendocinus, which occurred in high densities of 
626,103 ind. $\mathrm{m}^{-3}$ and 794,103 ind. $\mathrm{m}^{-3}$ in the dry and wet periods, respectively. Only two species of Protozoa (Lesquereusia modesta and Arcella $s p$.) were recorded, occurring in the flood period. Figures 3 and 4 show the absolute and relative abundances of the different developmental stages of the copepods. Nauplii were dominant in both the dry $(46 \%)$ and wet $(57.3 \%)$ periods. Copepodites represented $12 \%$ and $5.9 \%$ of the total, while adults represented $41.7 \%$ and $36.8 \%$, in the dry and wet periods, respectively. Unlike the nauplii, the copepodites, and especially the adults, were more numerous in the dry period.

\section{DISCUSSION}

In general, the river waters draining the basin and the rainfall are considered the main components of the hyrodological regime of the Pantanal (Adamoli, 1986; Carvalho, 1986; Tarifa, 1986). However, the hydrological regime of the subregion of Nhecolândia, where the present study was conducted, is strongly associated with local rainfall patterns (Abdon et al., 1997), with little direct contribution from rivers.

In addition, due to the differences in the relief of this sub-region and the presence of ridges ("cordilheiras") that lead to discontinuity in the

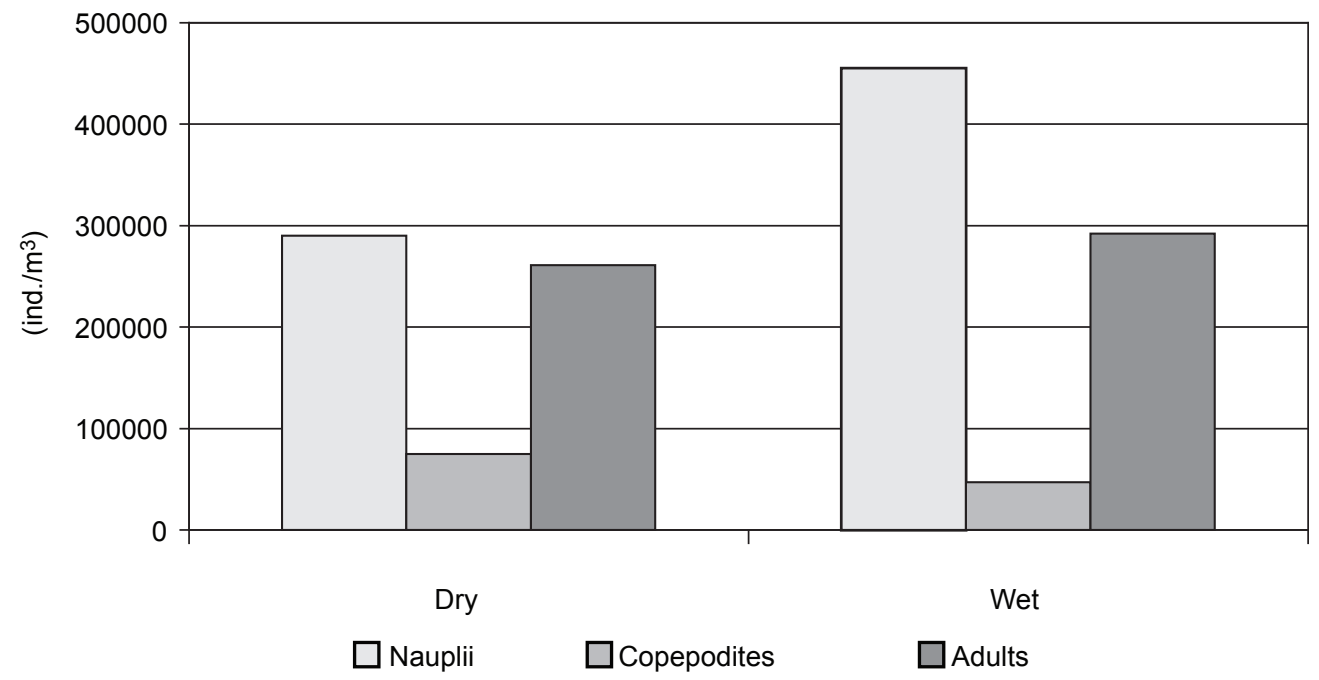

Fig. 3 - Numerical density of the developmental stages of Metacyclops mendocinus in the lake during the dry (Sep 1997) and wet (Jun 1998) periods.

Dry period

(\%)

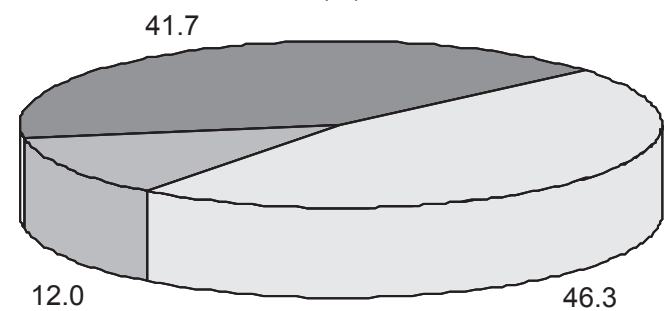

Wet period

(\%)

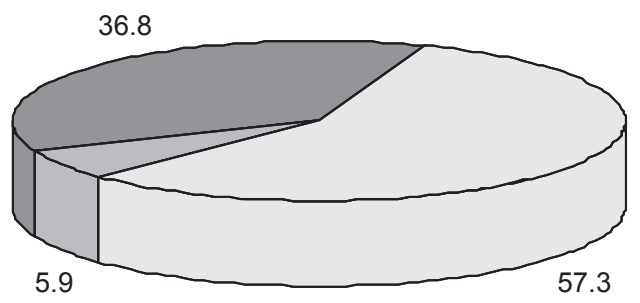

Fig. 4 - Relative abundance of the developmental stages of Metacyclops mendocinus in the lake during the dry (Sep 1997) and wet (Jun 1998) periods. 
inundated areas, the lakes on this plain show different degrees of coalescence with the system in flood, so that the saline lake in question belongs to the category that only rarely enters into contact with the entire system (Mourão et al., 1988).

Thus, the changes we found in water level between the dry and wet periods should be entirely due to the supply from subterranean sources and evaporation. According to observations by Sakamoto et al. (1996), the water table shows a slight inclination toward the saline lakes, indicating that this table is an important factor for maintaining water in these systems. In a study of the hydrological dynamics of one such saline lake, Queiroz-Neto et al. (2000) concluded that it was entirely supplied from the water table.

Examining the water balance of the same lake as the one studied here, Mourão (1989) recorded the occurrence of water deficits, with evaporation exceeding precipitation, which may explain the high concentration of salts found in this system. Upon studying the water balance of another salt lake of the region, Sakamoto (1997) verified the existence of a saline layer with a predominance of carbonates immediately under the lake. Possibly, this layer serves as a base that sustains the salinity of these systems through a continuous supply of subterranean water rich in salts, in combination with superficial evaporation.

The changes in water level found in the present study, with levels twofold higher during the wet period than in the dry, markedly influenced practically all the limnological variables analyzed, with an evident dilution in the concentration of dissolved and suspended substances during the wet period, except for nitrate, which displayed higher values in this period, and total phosphorus, whose concentrations were essentially similar in the two periods (Fig. 2).

The salt concentrations recorded $\left(4.60 \mathrm{gL}^{-1}\right.$ and 2.00 g.L $\mathrm{L}^{-1}$ in the dry and wet periods, respectively), together with the high values of electrical conductivity $\left(8470 \mu{\mathrm{s} . \mathrm{cm}^{-1}}^{-}\right.$and $3950 \mu \mathrm{s} . \mathrm{cm}^{-1}$ in the dry and wet periods, respectively), are similar to or higher than those recorded for systems in arid regions of Australia (Hart et al., 1991), Nigeria (Egborge, 1994) and Ethiopia (Tudorancea \& Harrinson, 1988). The salt concentration, allied with the high primary production, may have contributed to the high $\mathrm{pH}$ values recorded.

The significant contribution of the organic fraction in the suspended solids was probably due to phytoplankton, as evidenced by the extremely high concentrations of chlorophyll $a$, which reached $2064.6 \mu \mathrm{g} . \mathrm{L}^{-1}$ in the dry period, turning the water green and reducing its transparency.

The concentrations of chlorophyll $a$ were among the highest recorded for the most productive systems in the world. In a review of studies on tropical African lakes, Beadle (1974) observed a similar tendency for high photosynthetic production in the saline lakes of that continent. Furthermore, he found that the dense algal blooms of those systems were associated with a predominance of cyanobacteria, which appear to develop readily in saline environments, as in the case of Lake Araguandi (Ethiopia), a group of saline lakes near Lake Chad, and other small lakes situated in the Sahara.

Studying the same lake as the one investigated here, Mourão (1989) found a high concentration of chlorophyll $a\left(2297.00 \mu \mathrm{g} . \mathrm{L}^{-1}\right)$, with a predominance of cyanobacteria among the phytoplankton (represented by 7 genera, including Oscillatoria, Aphanothece and Anabaenopsis), and concluded that the ecological processes that favored the high concentration of chlorophyll $a$ in this system were similar to those occurring in Africa's saline lakes. The high photosynthetic productivity was likely the result of the ample availability of nutrients in the water, as well as the high temperatures, accelerating the biological processes.

On the other hand, the extremely high concentrations of total dissolved carbon may be attributed to the greater presence of carbonates in the system, as reported by Sakamoto (1997). This ion is likely responsible for the predominance of the inorganic form of carbon in the lake. According to Wetzel \& Likens (1991), carbonates are one of the principal forms of dissolved inorganic carbon in aquatic ecosystems. In addition, the peak in dissolved inorganic carbon recorded in the dry period was related to the $\mathrm{pH}$ values that reached 9.5. In accordance with Wetzel (1993), inorganic carbonate reaches extreme values in saline lakes with $\mathrm{pH}$ above 9.5.

With regard to nitrogen, it is possible that the lake receives significant quantities of forms of 
this nutrient from subterranean waters, since the latter drain sedimentary rocks (Queiroz-Neto et al. 2000). On the other hand, some cyanobacteria and other photosynthetic bacteria are efficient nitrogen fixers (Wetzel, 1993). In the environment studied here, cyanobacteria constitute the only phytoplankton recorded by Mourão (1989), and thus might contribute to the high concentrations of this nutrient in the lake. Research carried out in Lake George (Uganda) suggests that some cyanobacteria and other bacteria contribute significantly, via fixation, to the concentration of nitrogen found in that lake (Beadle, 1974). According to Beadle, in shallow lakes, principally those which are saline or alkaline, the great predominance of cyanobacteria determines the degree of nitrogen fixation, which is the major source of this nutrient in such systems.

The concentrations of phosphorus recorded indicate the presence of this element in the soil of the region (Wetzel, 1993), which, along with other elements, contains arenite as a potential source of phosphorus. According to EMBRAPA (1997), the Pantanal formation is predominant in the area of Nhumirim Ranch, consisting basically of arenite and clay, which may contribute to the high concentrations of this nutrient in the lake.

Furthermore, the absence of surface contact between the lake and the rest of the plain likely favors a pattern of nutrient recycling restricted to the lake basin itself. This may promote a continual storage of nutrients in the system, representing an important autochthonous organic contribution to the forms of carbon, nitrogen and phosphorus.

Our findings regarding the zooplankton community, represented basically by the cyclopoid copepod Metacyclops mendocinus, express the inverse relationship between diversity and dominance of organisms. The extremely low diversity is related to the high level of environmental stress recorded in the lake, with high values for most of the limnological variables in both periods (Table 2).

Jorgensen (1997) corroborates this hypothesis in affirming that ecosystems with a high capacity to resist prolonged stress generally have low biological diversity, usually accompanied by high density of organisms. Green (1993) also commented that, although great abundance may be due to multiple causes, this characteristic generally indicates a community subjected to intensive stress.
Among the factors that render this lake inhospitable for the zooplankton community, the high $\mathrm{pH}$ and dissolved salt concentration are notable, as also observed by other authors for equivalent systems. Studies of African (Beadle, 1974; Seaman et al., 1991), Australian (Green, 1993) and North American (Colburn, 1988) lakes have established a strong correlation between increases in salinity and reductions in biological diversity. These authors have found that, in continental ecosystems, salinity values above the typical limits for freshwaters causes marked reductions in species diversity, with only organisms with high osmoregularity capacity being able to survive. Based on microcosm experiments, Greenwald \& Hurlbert (1993) confirmed the negative effect of salinity on plankton. These authors also verified the greater success of cyclopoid copepods under conditions of elevated salinity in their tests. These environments may also favor the presence of Cyclopoida through food availability (Rietzler \& Espíndola, 1998), basically consisting of cyanobacteria.

According to Beadle (1974), extreme values of $\mathrm{pH}$ and alkalinity, generally associated with saline environments, affect the flora and fauna of these systems much more than does salinity. Using bioassays, Mourão et al. (1988) concluded that the $\mathrm{pH}$ of saline lakes is a limiting factor for fish survival in these systems. On the other hand, lakes in the vicinity of the saline lake of our study, possessing slightly acidic $\mathrm{pH}$ (varying between 6.0 and 7.0) and low concentrations of salts $\left(<1.0\right.$ g.L $\left.\mathrm{L}^{-1}\right)$, showed a higher zooplankton diversity, with up to 88 species found in a particular environment, including Copepoda, Rotifera and Cladocera (Medina-Jr, 2000).

Metacyclops mendocinus is considered a euryhaline species (Reid \& Moreno, 1990) and is commonly associated with high algal productivity (Reid, 1985), thus making it a ready colonizer of habitats like this saline lake. According to Reid \& Moreno (op.cit), this species was dominant in all the saline lakes of the region under study. This is to be expected, since this species has been recorded in other mesohaline environments, such as some lakes of the pampas region and the Lagoa dos Patos estuary (Rio Grande do Sul, Brazil), supporting even greater salinities than those recorded in Nhecolândia's lakes. 
This species' adaptation to the environmental characteristics of the saline lake is further evidenced by the high densities recorded. According to Dumont (1992), this characteristic is typical of continental saline lakes, where the extremely low number of taxa is always accompanied by notably elevated biomass.

Acknowledgments - The authors are indebted to the PPGSEA/EESC-USP; Centro de Pesquisas do Pantanal/EMBRAPA, especially to Débora F. Calheiros and Márcia Divina, for their logistic support, Kennedy Roche for the translation and revision of this article, and Sílvio Jaques Garnés for his support in the editorial business of the map. Financial support was provided by the Brazilian research institutions CAPES and CNPq.

\section{REFERENCES}

ABDON, M. M.; SILVA, J. S. V. \& GALDINO, S., 1997, Extensão da área alagada no período de cheia em parte da sub-região da Nhecolândia, no Pantanal, Brasil. In: Simpósio Latino Americano de Percepcion Remota, 8. Anais, Mérida, Venezuela.

ADÁMOLI, J., 1986, A dinâmica das inundações no Pantanal. In: Simpósio sobre recursos naturais e sócio-econômicos do Pantanal. Anais. Brasília, EMBRAPA.

BEADLE, L. C., 1974, The inland waters of Tropical Africa: an introduction to tropical limnology. Long man Group Limited, London, and $365 \mathrm{p}$.

CARVALHO, N. de O., 1986, Hidrologia da bacia do alto Paraguai. In: Simpósio sobre recursos naturais e sócioeconômicos do Pantanal. Anais. Brasília, EMBRAPA.

COLBURN, E. A., 1988, Factors influencing species diversity in saline waters of Death Valley, USA. Hydrobiol., 158: 215-226.

DUMONT, H. J., 1992, The regulation of plant and animal species and communities in African shallow lakes and wetlands. Rev. Hydrobiol. Trop., 4: 303-346.

DUSSART, B. H. \& DEFAYE, D., 1995, Copepoda: Introduction to the copepoda. Amsterdan, SPB (Guides to the identification of the microinvertebrates of the continental waters of the world, 7). $277 \mathrm{p}$.

EDMONDSOM, W. F., 1959, Fresh. Biol., 2. Ed., New York, John Wiley \& Sons.

EDMONDSOM, W. T. \& WIMBERG, G. C., 1971, A manual on methods for the assessment of secondary productynty in freshwaters. Oxford, Blackwell Scientific Publications, (IPB Handbook, n. 17). 358 p.

EGBORGE, A. B. M., 1994, Salinity and the distribution of rotifers in the Lagos Harbour - Badagry Creek system, Nigeria. Hydrobiol., 272: 95-104.

EMBRAPA, 1997, Plano de utilização da Fazenda Nhumirim. Corumbá, EMBRAPA, CPAP, documento 21, 72 p.

GOLTERMAN, H. L; CLYMO, R. S. \& OHNSTAND, M. A., 1978, Methods for physical and chemical analysis of freshwaters. $2^{\text {nd }}$ ed., Blackwell Scientific, IBP Hand-book, London, $213 \mathrm{p}$.
GREEN, J., 1993, Diversity and dominance in planktonic rotifers. Hydrobiol., 255-256: 345-352.

GREENWALD, G. M. \& HULBERT, S. H., 1993, Microcosm analysis effects on coastal lagoon plankton assemblages. Hydrobiol., 267: 307-335

HART, B.T.; BAILEY, P.; EDWARDS, R.; HORTLE, K.; JAMES, K.; McMAHON, A.; MEREDITH, C. \& SWADLING, K., 1991, A review of the salt sensitivity of the Australian freshwater biota. Hidrobiol., 210: 105-144.

HECKMAN, C. W., 1996, Fatores geográficos e climáticos determinantes das diferenças bióticas entre as partes norte e sul do Pantanal Mato-grossense. In: II Simpósio sobre recursos naturais e sócio-econômicos do Pantanal - manejo e conservação. Anais, Brasília, EMBRAPA.

JORGENSEN, S. E., 1997, Integration of ecosystem theories: a pattern. 2 ed. Dordrecht/Boston/London, Klwer Academic Publishes, $388 \mathrm{p}$.

JUNK, W. J., BAYLEY, D. B. \& SPARKS, R. E., 1989, The flood pulse concept in river floodplain. Can. Spec. Publ. Fih. Aquat. Sci., 106: 110-127.

KOROLEF, F., 1976, Determination of nutrients. In: Grasshoff, K. (ed). Methods of seawater analysis. Verlag. Chemie. Weinhein, $317 \mathrm{p}$.

MACKERETH, F. J. H., HERON, J. \& TALLING, J. F., 1978, Water analysis: some revised methods for limnologists. (Freshwater Biological Association Scientific Publication, 36). Titus Wilson \& Sons Ltda, Kendal, 117 p.

MATSUMURA-TUNDISI, T., 1986, Latitudinal distribution of Calanoid Copepods in freshwater aquatic systems of Brasil. Rev. Bras. Biol., 3: 527-553.

MEDINA-JR, P. B., 2000, Estrutura e diversidade da comunidade zooplanctônica em lagoas naturais do Pantanal de Nhecolândia-MS. 123 p. Dissertação de Mestrado - Escola de Engenharia de São Carlos, Universidade de São Paulo, São Carlos.

MOURÃO, G. de M., 1989, Limnologia comparativa de três lagoas (duas "baias" e uma "salina") do Pantanal da Nhecolândia, MS. São Carlos, 135 p. Dissertação de Mestrado. Universidade Federal de São Carlos.

MOURÃO, G. H.; ISHII, I. H. \& CAMPOS, Z. H. S., 1988, Alguns fatores limnológicos relacionados com a ictiofauna de baías e salinas do Pantanal da Nhecolândia, Mato Grosso do Sul, Brasil. Acta Limnol. Brasil., 11: 181-198.

PENNAK, R. W., 1953, Freshwater invertebrates of United States. The Ronald Press Company. 769 p.

QUEIROZ-NETO, J. P.; SAKAMOTO, A. Y.; LUCATI, H. M. \& FERNANDES, E., 2000, Dinâmica hídrica de uma lagoa salina e seu entorno na área do Leque, Nhecolândia (Pantanal-MS). In: II Simpósio sobre recursos naturais e sócio-econômicos do Pantanal. Anais, Brasília, EMBRAPA.

REDDY,Y.R., 1994,Copepoda: Calanoida: Diaptomidae: Key to the genera Heliodiaptomus, Allodiaptomus, Neodiaptomus, Phyllodiaptomus, Eodiaptomus, Arctodiaptomus and Sinodiaptomus. The Hague, SPB. 221 p.

REID, J. W., 1985, Chave de identificação e lista de referências bibliográficas para espécies continentais sul-americanas de 
vida livre de ordem Cyclopoida (Crustacea, Copepoda). $B$. Zool. USP, 9: 17-143.

REID, J. W. \& MORENO, I. H., 1990, The Copepoda (Crustacea) of the Southern Pantanal, Brazil. Acta Limnol. Brasil., 3: 721-739.

RIETZLER, A.C.\& ESPÍNDOLA, E.L.G., 1998, Microcystis as a food source for copepods in a subtropical eutrophic reservoir. Proc.Vehr. Internat. Verein. Limnol., 264: 2001-2005.

ROCHA, O. \& MATSUMURA-TUNDISI, T., 1976, Atlas do zooplâncton da Represa do Broa: Copepoda. São Carlos, Departamento de Ciências Biológicas/UFSCAR. 68 p.

SAKAMOTO, A. Y., 1997, Dinâmica Hídrica em uma lagoa "salina" e seu entorno no Pantanal da Nhecolândia: contribuição ao estudo da relação entre o meio físico e a ocupação, Fazenda São Miguel do Firme, MS. São Paulo, 183 p. Tese de Doutorado. Universidade de São Paulo.

SAKAMOTO, A. Y.; QUEIROZ-NETO, J. P.; FERNANDES, E. \& LUCATI, H.M., 1996, Topografia de lagoas salinas e seus entornos no Pantanal de Nhecolândia-MS. In: II Simpósio sobre recursos naturais e sócio-econômicos do Pantanal manejo e conservação. Anais. Brasília, Embrapa.

SEAMAN, M. T.; ASHTON, P. J. \& WILLIAMS, W. D., 1991, Inland salt waters of southern Africa. Hydrobiol., 210: 75-91

SILVA, J. V. \& ABDON, M. M., 1998, Delimitação do Pantanal brasileiro e suas sub-regiões. Pesq. agrop. Bras., 33: 1703-1711.
SORIANO, B. M. A., 2000, Caracterização Climática da subregião de Nhecolândia, Pantanal-MS. In: II Simpósio sobre recursos naturais e sócio econômicos do Pantanal. Anais, Brasilia, EMBPRAPA.

STANDARD METHODS., 1995, For examination of waterand wastwater. In: A. D. Eaton et al. (eds.). $19^{\text {th }}$ ed. American Public Health Association, Washington, 1268 p.

STRICKLAND, J. D. \& PARSONS, T. R., 1960, A manual of sea water analysis. Bull. Fish. Res. Be. Cam, 125: 1-185.

TARIFA, J. R., 1986, O sistema climático do Pantanal. Da compreensão do sistema à definição de prioridades de pesquisa climatológica. In: Simpósio Sobre Recursos Naturais e Sócio-Econômicos do Pantanal. Anais. Brasília, EMBRAPA.

TEIXEIRA, C.; TUNDISI, J. G. \& KUTNER, M B., 1965, Plankton studies in a mangrove environment II. The standing stock and some ecological factors. B. Inst. Oceanogr., 24: 23-41.

TUDORANCEA, C. \& HARRINSON, A. D., 1988, The benthic communities of the saline lakes Abijata and Shala (Ethiopia). Hydrobiol., 197: 91-97.

TUNDISI, J. G., 1969, Produção primária, "standing-stok" e fracionamento do fitoplânton na região lagunar de Cananéia. Tese de Doutorado, Universidade de São Paulo, São Paulo, 131 p.

WETZEL, R. G., 1993, Limnologia. Lisboa, Fundação Coloust Gulbenkian. 1016 p.

WETZEL, R. G. \& LIKENS, G. E., 1991, Limnological analysis. 2 ed. New York, W. B. Saunders Company. 391 p. 